\title{
Emerging animal viruses: real threats or simple bystanders? ${ }^{1}$
}

\author{
Eduardo Furtado Flores ${ }^{2 *}$, Rudi Weiblen ${ }^{2}$, Juliana Felipetto Cargnelutti ${ }^{2}$, Fernando \\ Viçosa Bauermann ${ }^{3}$, Fernando Rosado Spilki ${ }^{4}$, Enio Mori ${ }^{5}$ and Ana Cláudia Franco ${ }^{6}$
}

ABSTRACT.- Flores E.F., Weiblen R., Cargnelutti J.F., Bauermann F.V., Mori E., Spilki F.R. \& Franco A.C. 2013. Emerging animal viruses: real threats or simple bystanders? Pesquisa Veterinária Brasileira 33(10):1161-1173. Setor de Virologia, Departamento de Medicina Veterinária Preventiva, Centro de Ciências Rurais, Universidade Federal de Santa Maria, Av. Roraima 1000, Camobi, Santa Maria, RS 97105-900, Brazil. E-mail: eduardofurtadoflores@gmail.com

The list of animal viruses has been frequently added of new members raising permanent concerns to virologists and veterinarians. The pathogenic potential and association with disease have been clearly demonstrated for some, but not for all of these emerging viruses. This review describes recent discoveries of animal viruses and their potential relevance for veterinary practice. Dogs were considered refractory to influenza viruses until 2004, when an influenza A virus subtype H3N8 was transmitted from horses and produced severe respiratory disease in racing greyhounds in Florida/USA. The novel virus, named canine influenza virus (CIV), is considered now a separate virus lineage and has spread among urban canine population in the USA. A new pestivirus (Flaviviridae), tentatively called HoBi-like pestivirus, was identified in 2004 in commercial fetal bovine serum from Brazil. Hobi-like viruses are genetically and antigenically related to bovine viral diarrhea virus (BVDV) and induce similar clinical manifestations. These novel viruses seem to be widespread in Brazilian herds and have also been detected in Southeast Asia and Europe. In 2011, a novel mosquito-borne orthobunyavirus, named Schmallenberg virus (SBV), was associated with fever, drop in milk production, abortion and newborn malformation in cattle and sheep in Germany. Subsequently, the virus disseminated over several European countries and currently represents a real treat for animal health. The origin of SBV is still a matter of debate but it may be a reassortant from previous known bunyaviruses Shamonda and Satuperi. Hepatitis E virus (HEV, family Hepeviridae) is a long known agent of human acute hepatitis and in 1997 was first identified in pigs. Current data indicates that swine HEV is spread worldwide, mainly associated with subclinical infection. Two of the four HEV genotypes are zoonotic and may be transmitted between swine and human by contaminated water and undercooked pork meat. The current distribution and impact of HEV infection in swine production are largely unknown. Avian gyrovirus type 2 (AGV2) is a newly described Gyrovirus, family Circoviridae, which was unexpectedly found in sera of poultry suspected to be infected with chicken anemia virus (CAV). AGV2 is closely related to CAV but displays sufficient genomic differences to be classified as a distinct species. AGV2 seems to be distributed in Brazil and also in other countries but its pathogenic role for chickens is still under investigation. Finally, the long time and intensive search for animal relatives of human hepatitis C virus (HCV) has led to the identification of novel hepa-

\footnotetext{
${ }^{1}$ Received on September 3, 2013.

Accepted for publication on September 13, 2013.

${ }^{2}$ Setor de Virologia, Departamento de Medicina Veterinária Preventiva (DMVP), Centro de Ciências Rurais, Universidade Federal de Santa Maria (UFSM), Av. Roraima 1000, Camobi, Santa Maria, RS 97105-900, Brazil.*Corresponding author: eduardofurtadoflores@ gmail.com

${ }^{3}$ Ruminant Diseases and Immunology Research Unit, National Animal
}

Disease Center, Agricultural Research Service, United States Department of Agriculture (USDA), Ames, IA, USA.

${ }^{4}$ Laboratório de Microbiologia Molecular, Instituto de Ciências da Saúde, Universidade Feevale, Novo Hamburgo, RS 93352-000, Brazil.

${ }^{5}$ Instituto Pasteur, Av. Paulista 393, São Paulo, SP 01311-000, Brazil.

${ }^{6}$ Laboratório de Virologia, Instituto de Ciências Básicas da Saúde, Universidade Federal do Rio Grande do Sul (UFRGS), Rua Sarmento Leite 500, Porto Alegre, RS 90040-060, Brazil. 
civiruses in dogs (canine hepacivirus [CHV]), horses (non-primate hepaciviruses [NPHV] or Theiler's disease associated virus [TDAV]) and rodents. For these, a clear and definitive association with disease is still lacking and only time and investigation will tell whether they are real disease agents or simple spectators.

INDEX TERMS: Emerging viruses, animal pathogens, genetic evolution.

\begin{abstract}
RESUMO.- [Vírus emergentes de animais: verdadeiras ameaças ou meros espectadores?] 0 número de vírus
\end{abstract} animais cresce continuamente, causando preocupação permanente a virologistas e veterinários. 0 potencial patogênico e associação com doença tem sido claramente demonstrado para alguns - mas não para todos - vírus emergentes. Esse artigo apresenta uma breve revisão das recentes descobertas de vírus animais e a sua potencial relevância para saúde animal. Cães eram considerados refratários aos vírus da influenza até 2004, quando um vírus influenza A subtipo H3N8 foi transmitido de equinos e causou doença respiratória severa em cães galgos na Flórida/EUA. 0 novo vírus, denominado vírus da influenza canina (CIV), agora considerado uma linhagem distinta do vírus da influenza equina, disseminou-se na população canina urbana dos EUA. Um novo Pestivirus (Flaviviridae) - provisoriamente denominado pestivírus Hobi-like - foi identificado em 2004 em soro fetal bovino importado do Brasil. Os vírus Hobi-like são genética e antigenicamente relacionados com o vírus da diarreia viral bovina (BVDV) e induzem manifestações clínicas semelhantes. A sua origem e distribuição são desconhecidas, mas estão aparentemente disseminados no rebanho brasileiro e já foram identificados no sudeste asiático e na Europa. Em 2011, um novo buniavírus transmitido por mosquitos, denominado vírus Schmallemberg (SBV), foi associado com febre, redução da produção de leite, abortos e malformações fetais em bovinos e ovinos da Alemanha. Subsequentemente, esse agente se disseminou por vários países europeus e atualmente representa uma séria ameaça para saúde animal naquele continente. A origem do SBV é um tema ainda controverso, mas possivelmente tenha resultado de ressortimento entre os buniavírus Shamonda e Satuperi. 0 vírus da hepatite E (HEV, família Hepeviridae) é um conhecido agente de hepatite aguda em humanos e, em 1997, foi identificado pela primeira vez em suínos. Estudos epidemiológicos posteriores revelaram que o HEV está amplamente distribuído em rebanhos suínos, principalmente associado com infecção subclínica. Dois dos quatro sorotipos do HEV são zoonóticos e podem ser transmitidos entre suínos e humanos por água contaminada e carne mal-cozida. A distribuição atual e impacto da infecção pelo HEV na produção suína são desconhecidos. 0 girovírus aviário tipo 2 (AGV-2) é um novo girovírus, família Circoviridae, identificado no sangue de galinhas com suspeita de infecção pelo vírus da anemia aviária (CAV). 0 AGV-2 é estreitamente relacionado ao $\mathrm{CAV}$, mas apresenta diferenças genômicas que justificam sua classificação como espécie viral distinta. 0 AGV-2 parece estar amplamente distribuído em galinhas no Brasil e também em outros países, mas seu potencial patogênico ainda é desconhecido. Finalmente, a longa e intensiva busca por vírus animais relacionados ao vírus da hepatite C humana (HCV) tem levado a identificação de "novos" pestivírus em cães (canine hepacivirus [CHV]), equinos (hepacivirus de não-primatas [NPHV] ou vírus associado à doença de Theiler [TDAV]) e em roedores. Para estes, uma associação clara e definitiva com doença ainda não foi demonstrada e apenas tempo e investigação irão dizer se são patógenos reais ou apenas espectadores.

TERMOS DE INDEXAÇÃO: Vírus emergentes, patógenos animais, evolução genética.

\section{INTRODUCTION}

The recent years have witnessed the emergence of several animal viruses that challenge virologists, veterinarians and may threaten animal health. For some of these viruses, the pathogenic potential and association with disease were clearly demonstrated along or soon after their discovery (Crawford et al. 2005, Gibbens 2012). Hence, these newly recognized agents were definitively added to the enormous list of animal pathogens deserving attention of veterinarians and animal health personnel. For others, however, a clear association with disease and sanitary relevance has yet to be demonstrated (Schirrmeier et al. 2004, Kapoor et al. 2011).

The list of animal viruses grows as the livestock industry expands up and intensifies, the interest in pets increases, ecological changes occur, research develops and new diagnostic techniques are developed and made available. As a consequence, the veterinary medicine has been gifted a number of new pathogens in the last decades. These include the emergence and constant evolution of canine parvovirus (CPV) (Parrish \& Carmichael 1983, Truyen \& Parrish 2013), the emergence of porcine respiratory and reproductive syndrome virus (Wensvoort 1993), porcine circovirus, Hendra virus (Selvey et al. 1995), Nipah virus (Lee et al. 1999), the extended geographical distribution of West Nile virus (Anderson et al. 1999) and the dissemination of new bluetongue virus (BTV) serotypes into the Europe (Enserink 2006), among others. Atypical pestiviruses (Schirrmeier et al. 2004) and Schmalemberg virus were identified in cattle; influenza virus crossed barrier species and jumped into dogs (Crawford et al. 2005); hepatitis E virus infection was detected in pigs (Meng et al. 1998); a novel circovirus was identified in chickens (Rijsewijk et al. 2011) and novel hepacivirus were detected in dogs and horses (Kapoor et al. 2011, Burbelo et al. 2012).

The reasons behind the emergence of these viruses are usually difficult to determine, are frequently complex and often involve multiple factors. Genetic evolution, ecological and/or epidemiological changes, host-pathogen adaptation and host range extension have been implicated in the emergence of some animal and human viruses. On the other hand, it is increasingly accepted that some of these emerging agents are not truly new viruses. But rather, some are old viruses recently recognized due to the appli- 
cation of newest and powerful techniques. Alternatively, "new-old" agents may be discovered as a consequence of crescent interest and intensive research on some human and animal diseases of unknown etiology. In particular, the recent development of powerful techniques for massive genomic sequencing has allowed for the discovery of a number of potential animal pathogens, including viruses. Thus, it is reasonable to predict that the coming years will keep bringing us a crescent number of animal viruses. As a consequence, writing texts or textbooks on veterinary virology will became increasingly challenging since it will demand a permanent and systematic updating. Additionally to the recognition of "new-old" agents, fully characterization of these viruses will likely increase demand for funding and trained laboratory work load.

This article presents a concise review of some emerging viruses that called attention of virologists and veterinarians in the last decade (Table 1). For some, the pathogenic potential has been already demonstrated and, as such, they were definitively added to the textbooks of veterinary medicine. For others, however, a clear evidence of involvement with disease is still lacking. For the time being they may be regarded as orphan viruses or, alternatively, viruses searching for a disease.

\section{Canine influenza virus (CIV)}

Domestic dogs (Canis familiaris) were historically considered refractory to influenza A viruses. No evidence of virus circulation and transmission in this species had been repor- epidemiologically distinct from currently circulating H3N8 equine influenza virus (EIV) in the USA. However, it remains unknown whether CIV infection in dogs has reached a stable level or the incidence is still increasing (Dubovi 2010, Rivailler et al. 2010).

In a retrospective study including serology, immunohistochemistry and RT-PCR, researchers in the United Kingdom (UK) detected H3N8 EIV from horse origin as the cause of a severe respiratory outbreak in English foxhounds in 2002, independent of the USA outbreak (Daly et al. 2008). The epizootic of H3N8 EIV in horses in Australia in 2007 also resulted in canine infection (Kirkland et al. 2010). However, in both events there was no evidence of horizontal transmission among dogs.

As the H3N8 CIV is a relatively novel pathogen in the canine population, dogs lack natural immunity against the virus. Thus, all dogs, regardless breed or age, are susceptible to H3N8 CIV infection and the virus rapidly spreads within dog populations. About $80 \%$ of infected animals develop clinical signs upon infection whereas $20-25 \%$ develop subclinical infection, but also shed and transmit the virus (Beeler 2009). Outbreaks can occur when clinically normal carriers come into contact with a naïve population (Jirjis et al. 2010).

The highest risk for exposure to CIV occurs in communal facilities where dogs are housed and/or placed in the following conditions: 1) high density populations; 2) high turnover rates; 3 ) indoor (closed-air) environments, such as racing kennels, dog shows, agility events, animal shelters, kennel boarding and

Table 1. Emerging animal viruses, distribution and association with disease

\begin{tabular}{|c|c|c|c|c|}
\hline Virus & Family & Distribution & Especies & Clinical involvement \\
\hline $\begin{array}{l}\text { Canine influenza virus } \\
\text { virus }\end{array}$ & Orthomyxoviridae & Several US states & Dogs & $\begin{array}{l}\text { Respiratory disease, pneumonia, } \\
\text { subclinical infection }\end{array}$ \\
\hline Hobi-like pestivirus & Flaviviridae & $\begin{array}{l}\text { Brazil, Southeast } \\
\text { Asia, Italy }\end{array}$ & $\begin{array}{l}\text { Cattle, } \\
\text { Buffaloes }\end{array}$ & $?$ \\
\hline Schmallemberg virus & Bunyaviridae & Europe & Cattle, sheep, goats & $\begin{array}{l}\text { Neonatal malformation, abortion, } \\
\text { fever, drop in milk production }\end{array}$ \\
\hline $\begin{array}{l}\text { Swine hepatitis } \\
\text { E virus }\end{array}$ & Hepeviridae & Worldwide & $\begin{array}{l}\text { Swine, wild boars, rabbits, } \\
\text { rats, deer, mongoose }\end{array}$ & ? \\
\hline Avian gyrovirus 2 & Circoviridae & Brazil, Netherlands & Chickens & $?$ \\
\hline Canine hepacivirus & Flaviviridae & US & Dogs, horses & Mild respiratory disease (CHV) \\
\hline Non-primate hepacivirus & & US, United Kingdom & Horses & $\begin{array}{l}\text { Acute serum hepatitis, persistent } \\
\text { infection (NPHV) }\end{array}$ \\
\hline Rodent, bat hepaciviruses & & Worldwide & Rodents, bats & $?$ \\
\hline
\end{tabular}

ted up to a decade ago. Then, transmission of influenza virus H3N8 subtype from horses to dogs occurred in the state of Florida/USA in 2004, causing an outbreak of fatal respiratory disease in racing greyhound dogs (fatality rate of $36 \%$ ). The spillover host infection of $\mathrm{H} 3 \mathrm{~N} 8$ virus is related to the proximity of racehorses to racing greyhounds enabled this virus (H3N8) to infect a spillover host (Crawford et al. 2005).

This highly contagious agent seemed to adapt to the new host and most dog infections were mild followed by prompt clinical improvement. By the time, the virus was considered a canine-specific lineage of H3N8, referred as the canine influenza virus (CIV). H3N8 CIV infections spread among canine population (both racing greyhounds and pet dogs) of the USA, without association with outbreaks of equine influenza, supporting horizontal transmission among dogs. H3N8 CIV isolates formed a monophyletic group molecularly and training facilities, veterinary clinics, pet day-care centers, pet stores, and pet grooming salons (Crawford et al. 2005, Payungporn et al. 2008, Beeler 2009, Dubovi 2010, Hayward et al. 2010, Holt et al. 2010). Additionally, stressful situations, such as travel, prolonged endurance exercise in severe weather, and exposure to harsh terrain -, might increase the risk for influenza infection in dogs (Pecoraro et al. 2012).

Currently, canine influenza (CI) caused by H3N8 is considered an endemic disease in metropolitan areas of the Northeastern and Western regions of the USA and is apparently independent of equine influenza, resulting in high morbidity $(80 \%)$ and low mortality (1-5\%) in the dog population. CIV infection is not considered a seasonal flu and dog infections can occur year-round (Crawford et al. 2005, Payungporn et al. 2008, Beeler 2009, Dubovi 2010, Hayward et al. 2010, Holt et al. 2010, Rivailler et al. 2010). 
Molecular analysis of the eight genes of the CIV A/canine/ Florida/43/2004 (H3N8), obtained from the greyhound dogs, revealed nucleotide identity higher than $96 \%$ comparing with Florida sub-lineage isolates (clade 1 ) that circulate in the USA since early 1990s. The presence of all eight CIV genes of equine origin indicates transmission of the whole virus from horses to dogs, without reassortment events (Crawford et al. 2005, Payungporn et al. 2008, Hayward et al. 2010, Rivailler et al. 2010). Evidences to date support that the spillover resulted from a single event of virus transmission with subsequent adaptation to the new host. Five amino acid changes (N54K, N83S, W222L, I328T, and N483T) in the hemagglutinin (HA) gene were detected that distinguish H3N8 CIV from its ancestor H3N8 EIV (Crawford et al. 2005, Payungporn et al. 2008).

CIV is transmitted by direct contact, through aerosols generated by coughing and sneezing and by indirect contact through fomites contaminated with respiratory secretions and by people handling septic animals (Crawford et al. 2005). The incubation period is usually less than five days, with the highest shedding occurring before the development of clinical signs (Crawford et al. 2005, Deshpande et al. 2009, Dubovi 2010). CIV replicates in the respiratory epithelium, causing tracheitis, bronchitis and bronchiolitis (Crawford et al. 2005). As a result, the defense mechanisms of the respiratory tract become severely compromised, predisposing to secondary infections by bacteria or mycoplasma. Dogs of all ages seem to be equally susceptible to CIV-associate pneumonia (Dubovi 2010).

Most dogs develop a mild form of the disease, characterized by persistent fever for one to four days $\left(>39.4^{\circ} \mathrm{C}\right)$, depression, apathy, anorexia, sneezing, nasal and ocular discharge. The cough is usually non-productive and persists for 10 to 30 days. Most dogs eradicate the infection and recover clinically within two weeks (Beeler 2009, Dubovi 2010). As the clinical disease associated with CIV infection is similar to that observed in "kennel cough" or infectious tracheobronchitis, CI diagnosis requires laboratory confirmation (Mochizuki et al. 2008), usually virus isolation, RT-PCR and/or testing of paired serum samples by hemagglutining inhibition (HI) (Deshpande et al. 2009, Dubovi 2010). ELISAs to horse H3N8 are not recommended for diagnosis in dogs due to the low sensitivity (Crawford et al. 2005, Pecoraro et al. 2012).

Treatment consists mainly of supportive care, including antibiotics for secondary bacterial infections and hydration (Beeler 2009). Preventive measures include isolation of sick dogs and decontamination of premises with quaternary ammonium or sodium hypochlorite. Contact of horses with dogs should be avoided during outbreaks of equine influenza (Beeler 2009).

Vaccination of dogs against H3N8 CIV has been authorized in the USA since 2009, but vaccination should be restricted to animals that travel to high-risk areas experiencing canine or equine influenza (Deshpande et al. 2009). Vaccination significantly reduces virus shedding and the severity and duration of clinical disease, including the incidence and severity of lung damage (Deshpande et al. 2009).

The emergence of CIV in dogs is well characterized and is clearly derived from the transfer of a single EIV ancestor. CIV H3N8 spread efficiently among dogs and now circulates in at least 28 USA states (Anonymous 2013a). Despite description of occasional outbreaks in USA, the current incidence trends remain unclear (Hayward et al. 2010, Pecoraro et al. 2012).

\section{Hobi-like pestiviruses}

The genus Pestivirus, family Flaviviridae, is composed by four important pathogens of livestock: bovine viral diarrhea virus types 1 and 2 (BVDV1 and BVDV2), classical swine fever virus (CSFV) and border disease virus of sheep (BDV) (Simmonds 2013). BVDV1 and BVDV2 are major pathogens of cattle and infection results in significant economic losses worldwide. The pestivirus genome is composed by a positive single stranded RNA molecule around $12.3 \mathrm{~kb}$ in length, containing a single open reading frame (ORF) flanked by two untranslated regions (5' UTR and 3'UTR) (Simmonds 2013). The 5'UTR region is highly conserved among pestiviruses and the comparison of this region is widely accepted for phylogenetic analysis as well as the comparison of sequences coding for the viral proteins $\mathrm{N}^{\text {pro }}$, Erns and E2.

In addition to the recognized species, four proposed Pestivirus species remain officially unrecognized (Fig.1). Nominated following the first isolate - HoBi_D32/00 - Hobi-like viruses, also known as BVDV3 or atypical pestiviruses, has been initially identified in Europe in fetal bovine serum (FBS) imported from Brazil (Schirrmeier et al. 2004). Hobi-like viruses are related to BVDV at the genetic and antigenic levels. Further, the disease caused by these new viruses resembles the clinical presentations historically associated with BVDV infection, including decrease in circulating white blood cells, growth retardation, respiratory disease, reduced reproductive performance, and increased mortality among young stock (Cortez et al. 2006, Decaro et al. 2011, Bauermann et al. 2012, 2013a, Ridpath et al. 2013). The current BVDV diagnostic tests may fail to detect and/or differentiate Hobi-like viruses and the serological response they induce (Bauermann et al. 2012, Larska et al. 2012). Li-

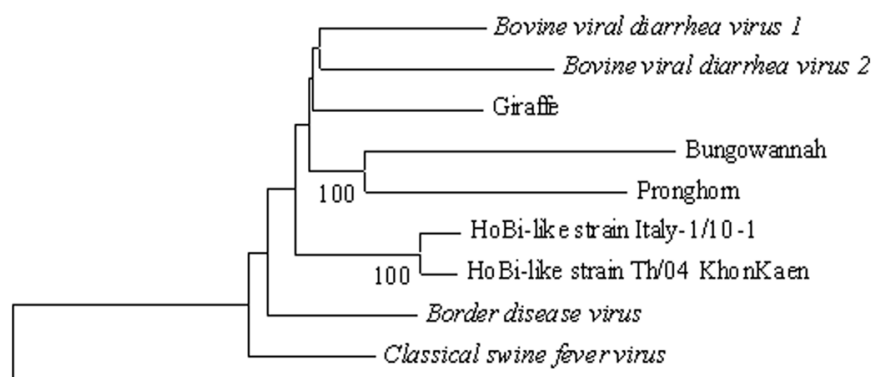

Hepatitis C

\section{2}

Fig1. Recognized and putative pestivirus species. Two HoBi-like strains are presented to demonstrate the variability and probably the existence of subgenotypes within this pestivirus group. The evolutionary history was inferred using the Neighbor-Joining method. All positions containing gaps and missing data were eliminated. Nucleotides from 5' UTR to E2 were analyzed. The percentage of replicate trees in which the associated taxa clustered together in the bootstrap test (1000 replicates) are shown next to the branches. Evolutionary analyses were conducted in MEGA5 (Tamura et al. 2011). 
kewise, both BVDV killed or modified live vaccines seem to induce weak cross protection to Hobi-like viruses (Bauermann et al. 2012, Bauermann et al. 2013b). This low cross-reactivity may be translated into a high number of animals unprotected against infection, shedding and generation of persistently infected calves. Due to reports of Hobi-like virus in Brazilian cattle herds, and description of contaminated Brazilian FBS, it is assumed that Hobi-like viruses are widespread in Brazilian herds (Cortez et al. 2006, Bauermann et al. 2013b). Nevertheless, reports of Hobi-like virus in cattle herds in Southeast Asia and Europe demonstrated that these viruses are not restricted to South America (Decaro et al. 2011, Stahl et al. 2012).

The origin of Hobi-like viruses is unclear. One hypothesis is that these viruses originated in South America and then were introduced to other countries through contaminated biological products. Also, the ability of pestiviruses to infect other species than the primary host may explain the emergence of Hobi-like viruses in cattle. One of the first Hobi isolates (BrazBuf9, reported by Stalder et al. 2005) was identified in the late 90's in water buffalos in Brazil (Bauermann et al. 2013b). Regardless whether Hobi-like virus was originated in other species than cattle, current data support that the virus is well adapted and widespread in cattle populations.

The first evidence of Hobi-like virus infections in Brazilian herds came from Cortez et al. (2006) who identified the agent in aborted fetuses (dated 2002 and 2004) in South eastern Brazil. Additional evidence of the circulation of the virus in the country was reported by Bianchi et al. (2011) who isolated and characterized a number of isolates. One isolate was identified in commercial frozen semen sample following description of blindness in newborn calves in herds using this semen. Two other viruses were identified in samples from herds with history of reproductive failure in Southern Brazil.

Cases of Hobi-like viruses infecting cattle in countries other than Brazil were reported in Thailand (Ståhl et al. 2007). An epidemiological study demonstrated that animals in four herds seroconverted to Hobi-like viruses, although no clinical signs were observed. Using heat inactivated serum samples, one calf was identified as positive for Hobi-like virus using antigen capture enzyme linked immunosorbent assay (ACE). Later in Italy, 2009, Hobi-like virus emerged in an outbreak of respiratory disease affecting 26 calves aging 6 to 7 months-old (Decaro et al. 2011). Hobi-like virus was detected by qRT-PCR in nasal discharge samples of six calves and in the lungs of the two dead animals. The clinical signs included fever $\left(39.4^{\circ}-40.1^{\circ} \mathrm{C}\right)$, cough, seromucoid nasal discharge, leukopenia, and accelerated pulse and breath (Decaro et al. 2011). Experimental infection of calves with Hobi-like virus leads to unapparent to mild clinical signs including increased body temperature and decreased white blood cell levels (Schirrmeier et al. 2004, Ridpath et al. 2013). Bilateral moderate conjunctivitis, watery-mucoid nasal and ocular discharge and cough were also described inoculating the Hobi-like isolate Th04_Khonkaen in 3-5 months old calves (Larska et al. 2012). Decaro et al. (2011) demonstrated that sheep are susceptible to HoBi-like virus isolate Italy-1/10-1, and yet no increase in body temperature was observed, depletion in circulating lymphocytes and moderate to abundant nasal discharge was observed. Infection of pigs with the Hobi isolates HoBi_D32/00 or Italy-1/10-1 led to seroconvertion, although no clinical sign was detected (Schirrmeier et al. 2004, Decaro et al. 2011).

The relatedness of Hobi-like viruses and BVDV species are also a major concern regarding BVDV control and eradication programs. On one hand, some BVDV assays as ACE are able to detected Hobi-like virus, on the other hand, the sensitivity of pair of primers known so far as "panpestiviruses" may lead to elevate number of false negative results (Bauermann et al. 2012, Bauermann et al. 2013a, Larska et al. 2012). Moreover, indicative information whether herds were exposed to different bovine pestiviruses may be achieved by analyses of the serologic response when comparing the antibody neutralizing titers of the serum against BVDV1, BVDV2, and Hobi virus (Bauermann et al. 2013a). On the other hand, the use of BVDV antibody detection ELISA kits for detection of animals exposed to Hobi-like viruses may generate high levels of false negative results, and the detection of positive samples is usually delayed (1 to 2 weeks) when comparing with virus-neutralization test detection (Bauermann et al. 2012, Larska et al. 2012).

Most cases of Hobi-like virus infection to date course subclinically or with mild disease and may, therefore, undergo undiagnosed. As a consequence, it is difficult to determine the economic impact of the disease. In addition, in regions where BVDV species and Hobi-virus cocirculate, the determination whether the economical losses are due to one virus or a "synergistic" effect of both is difficult to determine. Identification of Hobi-like viruses may be overlooked at field conditions due clinical presentation resembling BVDV infection. Also, available BVDV diagnostic tests may fail to detect/differentiate these agents, thus, the use of specific diagnostic tests must be applied. In addition, biological products containing FBS should be carefully screened avoiding further dissemination of the agent. The spread of Hobi-like viruses into naive regions might have profound effects on cattle production, and may also affect the status of bovine pestivirus free that some regions achieved following immense efforts.

\section{Schmalemberg virus}

In Summer-Autumn 2011, a novel virus associated with fever and drop in milk production was detected in cattle in northwestern Germany. Metagenomic analysis performed in blood samples from sick cattle revealed a new Orthobunyavirus (Hoffmann et al. 2012). The agent was then temptatively named Schmallenberg virus (SBV), a reference to the county of its first detection (Tarlinton et al. 2012). Following SBV detection in Germany, the emerging virus was detected causing diarrhea, abortion in cattle and fetal malformations in lambs in The Netherlands (Doceul et al. 2013). Subsequently, the virus was detected in blood, bovine and sheep fetuses in several European countries, including Belgium, France, United Kingdom, Italy, Spain, etc. SBV was detected in Europe all across 2012 and also in the next 
calving and lambing season (Autumn \& Summer 2012). Antibodies to SBV were also detected in alpacas, bisons, deer, red deer and mouflons in Europe, without association with clinical disease (Anonymous 2013b).

At this point, the origin of SBV remains unclear. The virus may have come with insects from Africa or, alternatively, SBV might have been circulating unnoticed or latently in a reservoir host in Europe (Tarlinton et al. 2012).

Genomic analysis has led to the allocation of SBV in the Orthobunyavirus genus of the family Bunyaviridae. Bunyaviruses are large, enveloped viruses containing a single-stranded, negative sense, segmented RNA genome consisting of three segments (large - L, medium - M and small - S) (Elliott 1990). The family comprises five genera: Hantavirus, Nairovirus, Orthobunyavirus, Phlebovirus and Tospovirus, and harbors important animal and human viruses, such as, akabane virus (AkV) and hantaviruses. In particular, the genus Orthobunyavirus contains 48 virus species grouped in serogroups (ICTV 2012).

Sequence analysis of the three SBV genomic segments revealed similarity with Shamonda virus (S segment: 97\% identity), Aino virus (M segment: $71 \%$ identity), and $\mathrm{AkV}$ (L segment: $69 \%$ identity). Thus, SBV is closely related to Shamonda virus, a member of the Simbu serogroup that also includes Simbu virus, Oropouche virus, AkV, Sathuperi virus and Aino virus, among others (Fig.2) (Hoffmann et al. 2012). Genomic studies have suggested that SBV could be the result of a ressortment between Sathuperi virus (M segment) and Shamonda ( $\mathrm{S}$ and $\mathrm{L}$ segments) (Yanase et al. 2012). However, sequencing and phylogenetic analysis of several orthobunyaviruses indicates that SBV is more closely related to Sathuperi than to Shamonda virus, suggesting that the novel virus may be, in fact, an ancestor of Shamonda virus (Goller et al. 2012). In any case, the definitive origin of this emerging virus is still uncertain and, as such, continues a matter of debate.

Epidemiological studies demonstrated that SBV is

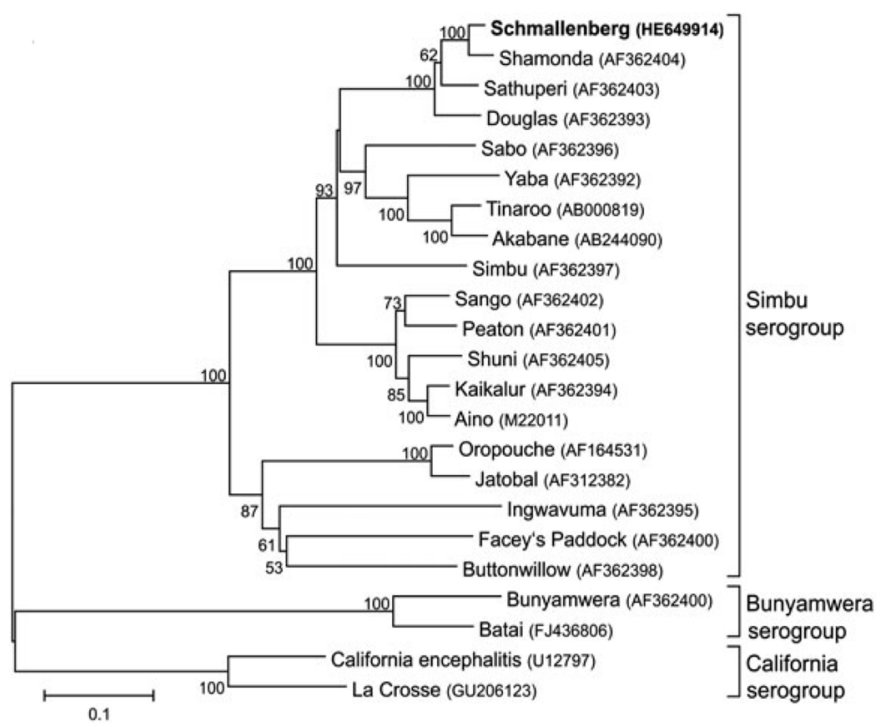

Fig.2. Phylogenetic relationship between Schmallenberg virus and orthobunyaviruses of the Simbu, Bunyamwera, and California serogroups, adapted from Hoffmann et al. (2012). transmitted by arthropod vectors, as most members of four genera of Bunyaviridae. SBV genomic RNA was detected in culicoides species during Summer 2011 in the Netherlan$\mathrm{ds}$, the same vectors involved in Blue tongue virus (BTV) transmission (Elbers et al. 2012). The SBV spreading in Europe is compatible with an arthropod vector and may reflect specific mosquito behavior (revised by Doceul et al. 2013). Direct transmission between animals is very unlikely, yet the virus may spread directly across the placenta (OIE 2013).

The seroprevalence of SBV in European herds is variable but, in general, high antibody titers have been detected. Seroprevalence was $72.5 \%$ in Netherland herds during winter 2011-2012 (Elbers et al. 2012). Retrospective serological studies (2006 to 2013) in domestic ruminant sera identified seroprevalence ranging from 1.5\% (buffaloes) to $39.5 \%$ (cattle) in Turkey (Azkur et al. 2013). Although SBV seroprevalence in Europe is high, the morbidity and mortality rates are estimated in less than 3\% in affected countries (revised by Doceul et al. 2013).

In general, clinical signs associated with SBV infection are more severe in cows than in sheep and goats. Infected cows present fever, diarrhea, malaise, loss of appetite and drop in milk production (Hoffmann et al. 2012). Infected animals develop short-lived viremia (until 5-6 days) which is enough to produce fetal infection in pregnant females (Hoffmann et al. 2012). Pregnant sheep, goats and cows may present high incidence of abortions and congenital malformations (revised by Doceul et al. 2013). The main malformations in the newborn are arthrogryposis, hydranencephaly, ataxia, torticollis, kyphosis, lordosis, scoliosis porencephaly, brain deformities and marked damage to the spinal cord (Anonymous 2013b). If the pathogenesis of SBV infection in pregnant ruminants is similar that of $\mathrm{AkV}$, fetal malformations would vary depending of the stage of gestation in which the infection occurs (Tarlinton et al. 2012). In addition to blood of adults, SBV RNA has been detected in the fetal brain and in placenta (Bilk et al. 2012, Hoffmann et al. 2012). Histopathological examination of the brain of newborn/aborted calves and lambs reveals inflammation, characterized by a lymphohistiocytic, infiltration of the grey and white matter (Herder et al. 2012). Immunohistochemistry of the brain identifies SBV antigens in neurons of the grey matter and in the grey matter of the spinal cord (Varela et al. 2013). In general, the pattern of lesions caused by SBV in domestic ruminants is similar to other orthobunyaviruses (Herder et al. 2012).

Diagnosis of SBV infection is mainly based on detection of genomic RNA, virus isolation and serology. Blood and central nervous system (CNS) are the samples/tissues used to detect SBV RNA by qRT-PCR (Bilk et al. 2012, Anonymous 2013b). The S-segment has been used as target to RT-qPCR and virus RNA was detected in different tissues of malformed lambs and calves, such as CNS, spleen, cartilage, placental fluid, umbilical cord and meconium (Bilk et al. 2012). Virus isolation can be performed in Vero, BHK-21 and KC (Culicoides variipennis larve) cells from blood and nervous tissues (revised by Doceul et al. 2013). Serology to detect neutralizing antibodies can be performed by virus 
neutralization test (VNT) in serum samples from cattle and thoracic fluid samples from aborted or stillborn lambs and calves. ELISAs to detected SBV antigens and anti-SBV antibody to are commercially available.

SBV prevention and control include measures to reduce virus transmission and the development of vaccines. A recently developed inactivated vaccine - not commercialized yet - induced a good neutralizing antibody response in cattle and sheep, reducing SBV viremia after challenge (Wernike et al. 2013). Compulsory notification of newborn malformations and restrictions on the import of live animals and semen from SBV positive areas are under consideration to reduce/avoid the introduction of the virus in free areas. Protection of susceptible animals from biting midges may also help in reducing exposure or infection (Doceul et al. 2013, OIE 2013).

SBV is a new emerging virus producing important disease in cows, sheep and goats, and is currently a matter of important concern to veterinarians and animal health authorities in Europe. Although morbidity and mortality rates are low, the introduction of SBV in naïve herds can produce large economics losses. In this sense, sanitary measures and vaccination (in development) are important to avoid SBV spread and its introduction in other countries and continents.

\section{Hepatitis E virus}

A former member of the Caliciviridae family, Hepatitis E virus (HEV) is now reclassified as the only member of the genus Hepevirus, family Hepeviridae (Vasickova et al. 2007). The viral particle is composed by a non-enveloped capsid, about $33 \mathrm{~nm}$ in diameter, which covers a single-stranded positive sense RNA genome of $7.2 \mathrm{~Kb}$ in length. The genome contains a unique short untranslated region at the 5 '-end (5'-UTR) and three coding regions referred to as ORF-1, ORF-2 and ORF-3, followed by a unique short untranslated region at 3'-end (3 '-UTR). The whole genome is coupled to a poly-A tail (Vasickova et al. 2007).

The first detection of HEV in pigs was reported in 1997 in United States (Meng et al. 1998). The authors also reportedly found antibodies to HEV in 15 conventional herds in the Midwestern (Meng et al. 1998). Even though HEV infections in human beings were not common at that time in the U.S., swine HEV showed its ubiquitous nature just from the beginning. More than this, the first swine HEV strains shared about $97 \%$ percent identity at the amino acid level with concurrent strains isolated in humans, showing the zoonotic potential of the virus (Meng et al. 1998). Nowadays, virtually all swine-producing countries have already reported the circulation of swine HEV. Although swine infection is spread worldwide, the cases of human HEV induced hepatitis are far more common in developing countries, indicating that poor levels of sanitation and inadequate disposal of swine manure may have an association with the epidemiology of human infection (Meng 2011). Four main genotypes are identified, two of them circulate among pigs and humans, thus many authors recognize HEV as an emerging zoonotic virus (Meng 2011).

The disease caused by HEV in humans have some si- milarities with that caused by the Hepatitis A virus (HAV), including the fecal-oral route of transmission and the absence of chronification. The mortality rate is remarkable higher in pregnant women, where HEV can cause the death of up to $20 \%$ of patients, while in the non-pregnant population HEV induces up to $4 \%$ of deaths (Aggarwal \& Jameel 2011).

Although HEV seems to be an important agent of human liver disease, the infection by swine HEV in pigs is subclinical (Meng et al. 1998). Gross pathological lesions are absent both in naturally and experimentally infected animals. Microscopic lesions including mild to moderate multifocal periportal lymphoplasmacytic hepatitis are often reported in the liver of infected pigs, without clinical signs (Meng et al. 1998). After infection, pigs become viremic and shed the virus on theirs feces from 8 days for up to 12 weeks. The immunity raised by the infection is long lasting and a prior infection with swine HEV prevents the onset of viremia and fecal shedding of the virus is also diminished in immune animals (Meng et al. 1998).

Four genotypes were reported for HEV, named 1-4, based on the analysis of the complete genome sequence or partial genomic regions including a 371-nt region in ORF1 and a 147-nt region in ORF2 (Mirazo et al. 2012). The genotype classification has a relationship with the host species infected and the geographical distribution of the virus (Mirazo et al. 2012). Viruses from all 4 genotypes were found causing disease in humans, whereas only genotypes 3 and 4 are found in pigs. HEV genotypes were further subdivided into subtypes, however, the current separation into some of the subtypes (specially within genotype 3 ) seems to be controversial (Oliveira-Filho et al. 2013).

Genotype 1 is mainly found in Asia and Africa, during HEV epidemics in humans; genotype 2 was firstly reported in Mexico and was further reported as an endemic virus in parts of Africa. As mentioned before, those genotypes are restricted to humans (Mirazo et al. 2012). Genotype 3 is worldwide distributed and has been causing infection in both humans and swines (Oliveira-Filho et al. 2013). This genotype is often associated to epidemics of HEV liver disease in humans in South America and is also found on swine in this same region (Oliveira-Filho et al. 2013). Moreover, genotype $3 \mathrm{HEV}$ strains were also found in many other animal reservoirs including wild boar, rabbits, rats, deer and mongoose (Vasickova et al. 2007). Similarly, genotype 4 HEV was detected in humans and pigs, as well in wild boars (Ishida et al. 2012); there are also some reports on the finding of genotype-4 like viruses in cattle, goats and sheep. Genotype 4 is particularly important causing sporadic cases of hepatitis in humans in Asia, and in recently reported cases of human liver disease in France (Okamoto 2007).

The ubiquitous nature of HEV infection in pigs suggests that contamination of meat products by HEV and viscera can be quite frequent. Approximately $2 \%$ of livers of pigs sold in grocery stores in Japan and $11 \%$ in the USA were positive for HEV genome (Wilhelm et al. 2011). The HEV-RNA prevalence in swine collected at abattoirs is highly variable: only $1 \%$ of bile samples in Hokkaido (Japan) (Wilhelm et al. 2011), 9.6\% of bile samples in Brazil (Santos et al. 2011) up 
to to $51 \%$ percent of swine bile samples were positive for the presence of HEV in Italy. Nucleotide sequences of HEV derived from commercial porcine livers are closely related, or identical in some cases, to those obtained from the virus recovered in human patients (Okano et al. 2013). Sporadic cases of acute hepatitis $E$ have been associated with the consumption of raw pork liver and undercooked contaminated pork or grilled meats (Meng 2011). Not only humans became infected by the consumption of pork byproducts, but it was also reported that the prevalence of HEV in pigs fed on kitchen residues was higher than in those fed on complete feed, thus indicating that indirect contact with infected humans is also a source of infection for pigs. Veterinarians and swine handlers are at higher risk of infection than the normal population (Wilhelm et al. 2011).

Another concern about HEV is the ability of the virus to contaminate water bodies and be transmitted by water. Many authors consider that contaminated water should constitute the major source of HEV infection in humans and the reason of ubiquity and perpetuation of the infection in pigs (Vasickova et al. 2007, Meng 2011). Outbreaks of HEV in humans tend to be more common in regions where conditions of water and sewage treatment are poor (Vasickova et al. 2007, Meng 2011). HEV was found contaminating the effluents of slaughterhouses and the virus is often found in swine manure storage facilities. The virus strains detected on swine herds and in the environmental matrices in a given geographic region are often phylogenetically related to those found in human cases of hepatitis occurred in people living nearby (Mirazo et al. 2012). These findings reinforces the need of control measures to avoid the contamination of the environment, including better management practices to deal with swine manure and even the use of vaccination of swine in the future.

\section{Avian gyrovirus 2}

Circoviruses are a growing group of non-enveloped, spherical viruses that contain circular, single-stranded DNA genomes. They belong to the family Circoviridae, which comprises the genus Circovirus and the genus Gyrovirus, and are able to infect a number of animal species. For more than 30 years, Chicken anemia virus (CAV) was the only gyrovirus known to infect chickens. However, this scenario changed with the discovery of the genome of a small DNA virus in chickens, in 2011, preliminarily named Avian gyrovirus 2 (AGV2) (Rijsewijk et al. 2011). The DNA of AGV2 was initially found in serum samples of poultry displaying signs of retarded growth, during a search of CAV DNA using multiple primer rolling circle amplification with random primers (MPRCA). Following the complete sequencing and sequence analysis of the amplified DNA (NCBI accession number HM590588), it was possible to demonstrate that it displays a similar genomic organization to that of CAV (Fig.3). Like $\mathrm{CAV}$, the AGV2 genome has a putative $5^{\prime}$ non transcribed region of about 400 nucleotides (nt), followed by three partially overlapping open reading frames encoding VP1, VP2 and VP3 homologs of CAV. The amino acid identities between each of these homologs and the respective segments of CAV are $38.8 \%, 40.3 \%$, and $32.2 \%$, respectively.
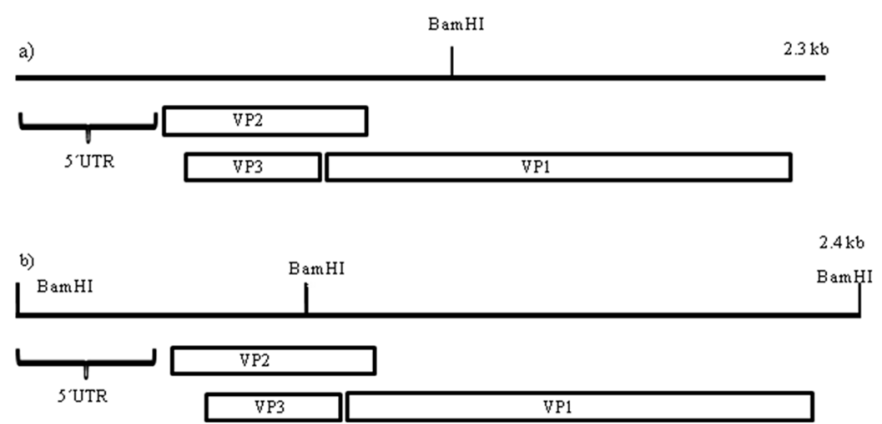

Fig.3. Schematic representation of the genomic organization of chicken anemia virus (CAV) (a) and avian gyrovirus 2 (AGV2) (b). The horizontal bars in the lower part represent the sizes and positions of VP2, VP3 and VP1 genes of both viruses. The nucleotide sites for BamHI in both genomes are indicated.

Since the first description of AGV2 in chickens, another complete genome sequence of AGV2, detected in fecal samples of children in China, became available (NCBI accession number JQ690763). In addition, other gyroviruses have been described in clinical and biological samples of humans (Sauvage et al. 2011, Chu et al. 2012, Maggi et al. 2012, Phan et al. 2012, Biagini et al. 2013) and chickens (Chu et al. 2012). The genomic similarities among the human gyroviruses and AGV2 indicate that they are closely related viruses (see Fig. 4), yet the clinical significance of the detection of viral DNA from these human samples still needs a deeper investigation. However, a detailed comparison of VP1, 2 and 3 of both AGV2 available sequences shows about $99 \%$ identity (Fig.4).

In addition to domestic chickens, AGV2 has also been found in samples of other birds. In a preliminary study to investigate AGV2 distribution in wild species, clinical and biological samples of sick and healthy animals were collected and submitted to virus DNA detection by PCR. AGV2 DNA was detected in an Alagoas curassow (Mitu mitu) (Lima et al. 2012) and in a Japanese quail (dos Santos et al. unpublished data). Although the role for AGV2 as a pathogenic virus for these animals was not proven, its identification in wild birds may have implications in the maintenance and dispersion of AGV2 in nature.

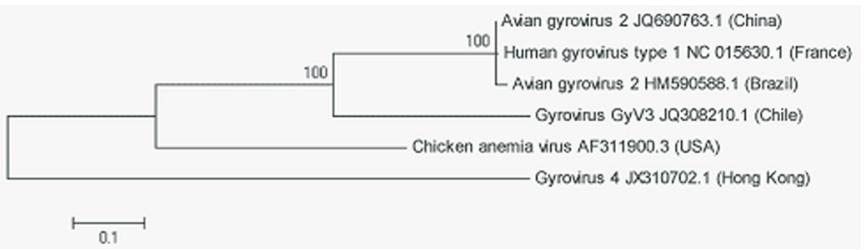

Fig.4. Molecular phylogenetic anaylsis based on the VP1 amino acid sequences of AGV2 (JQ690763 and HM590588), HGyV (NC015630.1), GyV3 (JQ308210.1), Gyrovirus 4 (JX310702.1) and CAV (AF311900.3). The analysis was performed by Maximum Likelihood method. The evolutionary history was inferred by using the Maximum Likelihood method based on the JTT matrix-based model [1]. The tree with the highest log likelihood (-3003.8159) is shown. The analysis involved 6 amino acid sequences. All positions containing gaps and missing data were eliminated. There were a total of 341 positions in the final dataset. Evolutionary analyses were conducted in MEGA5. 
Similar to other circoviruses, AGV2 seem to be quite resistant in nature. Virus DNA is easily found in commercial broiler litter and on the surface of the insects Alphitobius diaperinus, which is commonly found in commercial litters and known to harbor and preserve infectious viruses (Franco 2012). Interestingly, the virus is kept in an infectious state in broiler litter, as previously AGV2 negative chickens are infected after being in contact with AGV2 contaminated litters (Franco 2012). The detection of virus DNA in the environment is probably associated to a wide distribution of the virus in chickens, especially if this virus is resistant to unfavorable conditions as heat, UV incidence, dehydration, etc.

Circoviruses, like other eukaryotic ssDNA viruses, may display a high degree of genomic variation due to recombination (Lefeuvre et al. 2009, Martin et al. 2011) and high mutation rates (Duffy et al. 2008, Grigoras et al. 2010). This may facilitate the emergence and spread of some ssDNA viruses as pathogens of animals. However, these rules apparently do not apply equally to all members of the Circoviridae. While nucleotide variation in CAV genomes have been described, which allowed the classification of virus isolates in four distinct groups or genotypes (Eltahir et al. 2011), and the studies on molecular epidemiology of AGV2 are still scarce, genomic variation seem to exist at a higher frequency when compared to CAV (Santos et al. 2012, Muterle A.P. personal communication). In a study designed to establish the frequency of AGV2 in chickens in Southern Brazil, sequencing of the VP2/VP3 coding region revealed a higher degree of nucleotide variation than that commonly found in CAV isolates (Santos et al. 2012). These nucleotides changes in AGV2 variants lead to 5 and 8 amino acid changes, in VP2 and 3, respectively (Santos et al. 2012). Further comparative analysis of the amino acid sequences of the VP1 coding region of AGV2 of different origins, indicates that variation in this region also occurs (Muterle A.P. personal communication).

AGV2 DNA has been found in clinical samples of chickens from Southern Brazil and from the Netherlands. In the study mentioned above (Santos et al. 2012) the frequency of positive samples collected from Brazilian chickens which presented signs of retarded growth, loss of weight or brain lesions was $100 \%$. In the Netherlands, the frequency of AGV2 positive animals, among chickens which displayed brain lesions, was $42.9 \%$ (Santos et al. 2012). In addition, the same authors demonstrated that virus DNA is also readily detected in 60 to $85 \%$ of healthy chickens, depending on the geographic region. According to these preliminary results, AGV2 seems to be widespread in domestic chickens. However, further studies should be performed in order to evaluate the real distribution of this virus in other geographical regions.

The role of AGV2 as an etiologic agent for chickens is unclear at the present. The fact that AGV2 DNA can be also detected in samples of healthy chickens thwarts the establishment of an association between the virus and the development of disease. Consequently, the results obtained until now on the distribution of this virus in chickens may bring us to two possible scenarios. In the first, the virus is not pathogenic at all and is just one of the many viruses that have been recently discovered in clinical and biological samples of animals through metagenomic techniques (Foxman \& Iwasaki 2011, Mavrommatis et al. 2013). In the second scenario, AGV2 may indeed play a role as a pathogenic virus, but for the development of disease other elements are needed. Additional factors that could contribute to the development of disease are stress, mycotoxicosis, malnutrition or co-infections with other microorganisms, like bacteria and other viruses. If this is true, it would not be the first time that a circovirus is involved in multifactorial diseases (Schat 2009, Segales et al. 2013). Probably the most famous member of the family that, in association with a number of conditions, can cause a devastating disease in animals is Porcine circovirus type 2 (PCV2) (Segales et al. 2013). Nonetheless, definitive conclusions on the involvement of AGV2 in disease should be carefully examined in the future.

\section{Novel hepaciviruses of dogs, horses and rodents}

In the last years, the long time search for animal relatives (or ancestors) of human hepatitis $\mathrm{C}$ virus (HCV) has undercovered a number of hepaciviruses (Flaviviridae), some potentially relevant for veterinary practice. Although HCV was discovered more than two decades ago and chronically infects around 3\% of the world's population, its origin remains obscure. The host range of HCV is restricted and natural infection was detected only in humans. Non human primates are susceptible to experimental HCV infection (Bukl et al. 2010) and have been long suspected as harboring viruses related to $\mathrm{HCV}$, with potential transmission of some variants to humans (Simmonds 2013). However, no published evidence to date has been obtained for infection of HCV homologues in monkey species. The only known homolog is GB virus B (GBV-B) (Simons et al. 1995, Adams et al. 1998), which causes hepatitis in experimentally infected New World monkeys (Bukl et al. 2010). Hence, the finding of HCV relatives in other mammals would shed light on its origin/evolution and favor investigations on the biology and pathogenesis of this deadly human virus.

Investigating the viral flora of companion animals by high-throughput sequencing, Kapoor et al. (2011) identified a Flaviviridae agent in respiratory samples of dogs from two outbreaks of respiratory disease in shelters in the United States. Preliminary phylogenetic analysis of a 6.500 nt genomic sequence revealed the presence of a unique virus, most closely related to HCV (Fig.5). The authors suggested that the newly identified sequence/virus should be classified as a separate Hepacivirus species, and proposed the name canine hepacivirus (CHV). These findings raised the proposition that HCV might have evolved as a result of the close contact between dogs and humans during the past several thousand years, with a divergence time of dog and human viruses from a common ancestor within the past 500-1.000 years (Kapoor et al. 2011). However, subsequent investigations failed in detecting CHV sequences in nasal secretions of healthy dogs but occasionally detected related genomic sequences in a few livers of dogs which died of unexplained gastrointestinal disease. In any case, 


\section{Canine hepacivirus (CHV)}

$9,195 \mathrm{nt}(2,942$ aa polyprotein $)$

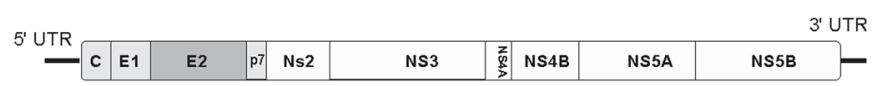

Theiler's Disease-associated virus (TDAV)

10,479 nt $(3,198$ aa polyprotein)

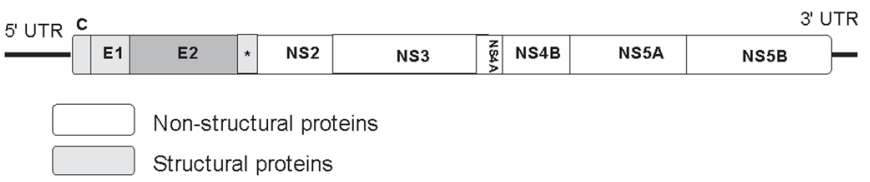

Fig.5. Genome organization of novel hepaciviruses identified in dogs (CHV) and horses (TDAV). The overall genome organization, number and putative functions of gene products and polyprotein cleavage sites are strikingly similar to those of GB virus and $\mathrm{HCV}$.

this achievement called attention of the scientific community since the long lasting search for the HCV ancestral might have come to an end.

In spite of the initial excitement, this achievement also raised a number of questions. First, whereas HCV and GBV-B are hepatotropic, it was not the case for CHV. Rather, the CHV genome was found in high titers in respiratory samples from sick dogs (Kapoor et al. 2011), suggesting a role for CHV in respiratory illness. Second, although CHV was detected in dogs from different outbreaks of respiratory disease, proofs were lacking that it was indeed a canine virus (Bukl et al. 2010). Third, it was surprising that CHV sequences recovered from respiratory or liver samples from dogs in different outbreaks were practically identical, contrasting with the genetic variation of HCV isolates. Fourth, subsequent screening of a number of healthy dogs from different locations failed to detect evidence of present or past exposure to CHV (Burbelo et al. 2012, Lyons et al. 2012). In addition, major questions were still holding: How is CHV transmitted to other dogs? Does it infect other mammals? Do CHV variants exist as observed for HCV? Does it cause persistent infections as HCV does? Is it restricted to dogs or infects other mammals? Thus, these and other questions should be obviously answered before considering CHV definitively a canine virus (Bukl et al. 2010, Simmonds 2013).

Regardless, the initial identification of this putatively novel hepacivirus in dogs caused a great deal of excitement and triggered a series of investigations. Then, a novel serology-based approach based on detection of antibodies to the highly conserved helicase domain of CHV NS3 was employed to search for exposure to related agents in several non-primate animal species ( 80 dogs, 14 rabbits, 81 deer, 84 cows and 103 horses) in New York state (Burbelo et al. 2012). No reactivity was observed in sera of dogs or in the other species either. Surprisingly, thirty-six samples from horses were immunoreactive, suggesting previous infection by a hepacivirus closely related to CHV in the helicase protein. In addition, viral genomic RNA was detected by PCR in sera of 8 of the 36 seropositive horses and in none of the seronegatives. Initial sequencing identified a series of genetically diverse viruses. Complete genome sequences revealed 8 genetically diverse viruses (average nucleotide divergence $14 \%$ ), tentatively named nonprimate hepaciviruses (NPHVs 1 to 8). Therefore, initially identified in dogs, hepaciviruses related to HCV were no longer detected in this species. Rather, HCV relatives were now identified in horses, raising the suspect that the outbreaks of infection in dog kennels were due to cross-species virus transmission.

Almost concomitantly, studies in Europe reinforced the latest hypothesis. Again, a PCR search for active CHV-like infection in domestic animals in the United Kingdom resulted negative in dogs (46 respiratory, 99 plasma, 45 autopsy samples), as well as in 362 samples from cats, donkeys, rodents and pigs (Lyons et al. 2012). Strickingly, three samples $(2 \%)$ from horses were serologically positive. Virological and clinical follow up of positive horses demonstrated hepacivirus persistence, high viral loads in plasma $\left(10^{5}-10^{7}\right.$ RNA copies/mL) and liver functions ranged from high normal to mildly elevated (Lyons et al. 2012). Moreover, the samples from the UK were genetically divergent from those NPHVs identified in horses in NY (Burbelo et al. 2012). At this point, the recent data indicated horses rather than dogs as the more likely hosts for this novel hepacivirus.

More recently, genome sequences of a novel and highly divergent member of the Flaviviridae were identified by massive parallel sequencing analysis of samples from horses suffering from acute hepatitis (Chandriani et al. 2013). Blood-derived acute hepatitis, known as Theiler's disease, has long been recognized in horses yet its etiology - in spite of continuous investigation - remains largely unknown. Thus, the new agent was temptatively called Theiler's disease associated virus (TDAV). Phylogenetic analyses clustered TDAV with GB viruses of the recent Pegivirus genus of the Flaviviridae, with a highly similar genomic organization (Fig.5). Regardless, a low aminoacid identity (35.5\%) was found with its closest GB relative, GB virus D. An epidemiological survey and experimental inoculation of horses with TDAV-positive plasma supported the association of TDAV with acute serum hepatitis. In addition, the agent displayed some key features of hepaciviruses associated with hepatitis, e.g. sustained viremia preceding liver injury, ability to produce persistent infection in some individuals and a low horizontal transmissibility. On the other hand, TADV is genetically divergent from non-primate hepacivirus (NPHV), previously identified in horses (Burbelo et al. 2012). Therefore, several lines of evidence point out TDAV as an etiological candidate for equine serum hepatitis. Whether TDAV is the sole virus or merely one of the several agents that may be associated with Theiler's disease - as occurs in human hepatitis - remain unclear at this point. On one hand, the identification of this novel agent with many biological similarities with HCV provides insights into the diversity of the Flaviviridae and opens opportunities to investigate a potentially important pathogen of horses (Chandriani et al. 2013). On the other hand, definitive proofs of the causal association of TADV and acute horse hepatitis are still lacking.

Regardless the origin and clinical relevance - and only time and investigation may answer - it seems clear that the 
discovery of hepaciviruses in dogs and horses was circumstantial. These viruses came out as a result of the intensive investigation carried out to identify animal relatives of $\mathrm{HCV}$ rather than as a result of investigations of disease etiology in these species. Such investigations, mainly if employing exquisite, massive and powerful molecular techniques, will probably gift us with a number of viruses, some of unknown pathogenic potential. In fact, recent articles described the detection of homologues of HCV and GBV in rodents and bats worldwide, extending the host range of these viruses (Kapoor et al. 2011, Drexler et al. 2013, Quan et al. 2013). In the case of TDAV, at least, evidences point out for a potential association with Theiler's disease. However, these discoveries are quite recent and the investigations have frequently changed directions. Thus, at this point, any interpretation should be cautious and definitive conclusions should be avoided.

\section{CONCLUSION}

As time and investigation keep on uncovering new animal viruses, the answer for the title question will also require continuous updating.

\section{REFERENCES}

Adams N.J., Prescott L.E., Jarvis L.M., Lewis J.C., McClure M.O., Smith D.B. \& Simmonds P. 1998. Detection in chimpanzees of a novel flavivirus related to GB virus-C/hepatitis G virus. J. Gen. Virol. 79( Pt 8):1871-1877.

Aggarwal R. \& Jameel S. 2011. Hepatitis E. Hepatology 54:2218-2226.

Anderson J.F., Andreadis T.G., Vossbrinck C.R., Tirrell S., Wakem E.M., French R.A., Garmendia A.E. \& Van Kruiningen H.J. 1999. Isolation of West Nile virus from mosquitoes, crows, and a Cooper's hawk in Connecticut. Science 286:2331-2333.

Anonymous 2013a. Emerging issues - Canine influenza: test summary for canine influenza virus in dogs not affiliated with greyhound racetracks. On line. Accessed in May 20, 2013. <http://ahdc.vet.cornell.edu/docs/ Statistics_for_Canine_Influenza_Virus.pdf $>$

Anonymous 2013b. Friedrich - Loeffler - Institut. Schmallenberg virus. On line. Accessed in June 6, 2013. <http://www.fli.bund.de/en>

Azkur A.K., Albayrak H., Risvanli A., Pestil Z., Ozan E., Yilmaz O., Tonbak S., Cavunt A., Kadi H., Macun H.C., Acar D., Ozenc E., Alparslan S. \& Bulut H. 2013. Antibodies to Schmallenberg virus in domestic livestock in Turkey. Trop. Anim. Health Prod. In press.

Bauermann F.V., Flores E.F. \& Ridpath J.F. 2012. Antigenic relationships between bovine viral diarrhea virus 1 and 2 and HoBi virus: possible impacts on diagnosis and control. J. Vet. Diagn. Invest. 24:253-261.

Bauermann F.V., Harmon A., Flores E.F., Falkenberg S.M., Reecy J.M. \& Rid-path J.F. 2013a. In vitro neutralization of HoBi-like viruses by antibodies in serum of cattle immunized with inactivated or modified live vaccines of bovine viral diarrhea viruses 1 and 2. Vet. Microbiol. 166:242-245.

Bauermann F.V., Ridpath J.F., Weiblen R. \& Flores E.F. 2013b. HoBi-like viruses: an emerging group of pestiviruses. J. Vet. Diagn. Invest. 25:6-15.

Beeler E. 2009. Influenza in dogs and cats. Vet. Clin. North. Am. Small. Anim. Pract. 39:251-264.

Biagini P., Bedarida S., Touinssi M., Galicher V. \& De Micco P. 2013. Human gyrovirus in healthy blood donors, France. Emerg. Infect. Dis. 19:10141015.

Bianchi E., Martins M., Weiblen R. \& Flores E.F. 2011. Perfil genotípico e antigênico de amostras do vírus da diarréia viral bovina isoladas no Rio Grande do Sul (2000-2010). Pesq. Vet. Bras. 31:649-655.

Bilk S., Schulze C., Fischer M., Beer M., Hlinak A. \& Hoffmann B. 2012. Organ distribution of Schmallenberg virus RNA in malformed newborns. Vet. Microbiol. 159:236-238.
Bukl J., Meuleman P., Tellier R., Engle R.E., Feinstone S.M., Eder G., Satterfield W.C., Govindarajan S., Krawczynski K., Miller R.H., Leroux-Roels G. \& Purcell R.H. 2010. Challenge pools of hepatitis C virus genotypes 1-6 prototype strains: replication fitness and pathogenicity in chimpanzees and human liver-chimeric mouse models. J. Infect. Dis. 201:1381-1389.

Burbelo P.D., Dubovi E.J., Simmonds P., Medina J.L., Henriquez J.A., Mishra N., Wagner J., Tokarz R., Cullen J.M., Iadarola M.J., Rice C.M., Lipkin W.I. \& Kapoor A. 2012. Serology-enabled discovery of genetically diverse hepaciviruses in a new host. J. Virol. 86:6171-6178.

Chandriani S., Skewes-Cox P., Zhong W., Ganem D.E., Divers T.J., Van Blaricum A.J., Tennant B.C. \& Kistler A.L. 2013. Identification of a previously undescribed divergent virus from the Flaviviridae family in an outbreak of equine serum hepatitis. Proc. Natl Acad. Sci. USA 110:E1407-1415.

Chu D.K., Poon L.L., Chiu S.S., Chan K.H., Ng E.M., Bauer I., Cheung T.K., Ng I.H., Guan Y., Wang D. \& Peiris J.S. 2012. Characterization of a novel gyrovirus in human stool and chicken meat. J. Clin. Virol. 55:209-213.

Cortez A., Heinemann M.B., De Castro A.M.M.G., Soares R.M., Pinto A.M.V., Alfieri A., Flores E.F., Leite R.C. \& Richtzenhain L.J. 2006. Genetic characterization of Brazilian bovine viral diarrhea virus isolates by partial nucleotide sequencing of the 5'-UTR region. Pesq. Vet. Bras. 26:211-216.

Crawford P.C., Dubovi E.J., Castleman W.L., Stephenson I., Gibbs E.P., Chen L., Smith C., Hill R.C., Ferro P., Pompey J., Bright R.A., Medina M.J., Johnson C.M., Olsen C.W., Cox N.J., Klimov A.I., Katz J.M. \& Donis R.O. 2005. Transmission of equine influenza virus to dogs. Science 310:482-485.

Daly J.M., Blunden A.S., Macrae S., Miller J., Bowman S.J., Kolodziejek J., Nowotny N. \& Smith K.C. 2008. Transmission of equine influenza virus to English foxhounds. Emerg. Infect. Dis. 14:461-464.

Decaro N., Lucente M.S., Mari V., Cirone F., Cordioli P., Camero M., Sciarretta R., Losurdo M., Lorusso E. \& Buonavoglia C. 2011. Atypical pestivirus and severe respiratory disease in calves, Europe. Emerg. Infect. Dis. 17:1549-1552.

Decaro N., Mari V., Lucente M.S., Sciarretta R., Moreno A., Armenise C., Losurdo M., Camero M., Lorusso E., Cordioli P. \& Buonavoglia C. 2012. Experimental infection of cattle, sheep and pigs with 'Hobi'-like pestivirus. Vet. Microbiol. 155:165-171.

Deshpande M.S., Jirjis F.F., Tubbs A.L., Jayappa H., Sweeney D., Spencer S.J., Lakshmanan N. \& Wasmoen T.L. 2009. Evaluation of the efficacy of a canine influenza virus (H3N8) vaccine in dogs following experimental challenge. Vet. Ther. 10:103-112.

Doceul V., Lara E., Sailleau C., Belbis G., Richardson J., Breard E., Viarouge C., Dominguez M., Hendrikx P., Calavas D., Desprat A., Languille J., Comtet L., Pourquier P., Eleouet J.F., Delmas B., Marianneau P., Vitour D. \& Zientara S. 2013. Epidemiology, molecular virology and diagnostics of Schmallenberg virus, an emerging orthobunyavirus in Europe. Vet. Res. 44:31.

Dos Santos D.R., De Paula V.S., De Oliveira J.M., Marchevsky R.S. \& Pinto M.A. 2011. Hepatitis E virus in swine and effluent samples from slaughterhouses in Brazil. Vet. Microbiol. 149:236-241.

Dos Santos H.F., Knak M.B., De Castro F.L., Slongo J., Ritterbusch G.A., Klein T.A., Esteves P.A., Silva A.D., Trevisol I.M., Claassen E.A., Cornelissen L.A., Lovato M., Franco A.C., Roehe P.M. \& Rijsewijk F.A. 2012. Variants of the recently discovered avian gyrovirus 2 are detected in Southern Brazil and The Netherlands. Vet. Microbiol. 155:230-236.

Drexler J.F., Corman V.M., Muller M.A., Lukashev A.N., Gmyl A., Coutard B., Adam A., Ritz D., Leijten L.M., Van Riel D., Kallies R., Klose S.M., Gloza-Rausch F., Binger T., Annan A., Adu-Sarkodie Y., Oppong S., Bourgarel M., Rupp D., Hoffmann B., Schlegel M., Kummerer B.M., Kruger D.H., SchmidtChanasit J., Setien A.A., Cottontail V.M., Hemachudha T., Wacharapluesadee S., Osterrieder K., Bartenschlager R., Matthee S., Beer M., Kuiken T., Reusken C., Leroy E.M., Ulrich R.G. \& Drosten C. 2013. Evidence for novel hepaciviruses in rodents. PLoS Pathog. 9:e1003438.

Dubovi E.J. 2010. Canine influenza. Vet. Clin. North. Am. Small. Anim. Pract. 40:1063-1071.

Duffy S., Shackelton L.A. \& Holmes E.C. 2008. Rates of evolutionary change in viruses: patterns and determinants. Natl Rev. Genet. 9:267-276.

Elbers A.R., Loeffen W.L., Quak S., De Boer-Luijtze E., Van Der Spek A.N., Bouwstra R., Maas R., Spierenburg M.A., De Kluijver E.P., Van Schaik G. 
\& Van Der Poel W.H. 2012. Seroprevalence of Schmallenberg virus antibodies among dairy cattle, the Netherlands, winter 2011-2012. Emerg. Infect. Dis. 18:1065-1071.

Elliott R.M. 1990. Molecular biology of the Bunyaviridae. J. Gen. Virol. 71:501-522.

Eltahir Y.M., Qian K., Jin W. \& Qin A. 2011. Analysis of chicken anemia virus genome: evidence of intersubtype recombination. Virol. J. 8:512.

Enserink M. 2006. Emerging infectious diseases. During a hot summer, bluetongue virus invades northern Europe. Science 313:1218-1219.

Foxman E.F. \& Iwasaki A. 2011. Genome-virome interactions: examining the role of common viral infections in complex disease. Natl Rev. Microbiol. 9:254-264.

Franco A.C. 2012 Avian gyrovirus 2. Presented at the round table: Emerging viruses. XXIII Congresso Brasileiro de Virologia, Foz do Iguaçu, PR.

Gibbens N. 2012. Schmallenberg virus: a novel viral disease in northern Europe. Vet. Rec. 170:58.

Goller K.V., Hoper D., Schirrmeier H., Mettenleiter T.C. \& Beer M. 2012. Schmallenberg virus as possible ancestor of Shamonda virus. Emerg. Infect. Dis. 18:1644-1646.

Grigoras I., Timchenko T., Grande-Perez A., Katul L., Vetten H.J. \& Gronenborn B. 2010. High variability and rapid evolution of a nanovirus. J. Virol. 84:9105-9117.

Hayward J.J., Dubovi E.J., Scarlett J.M., Janeczko S., Holmes E.C. \& Parrish C.R. 2010. Microevolution of canine influenza virus in shelters and its molecular epidemiology in the United States. J. Virol. 84:12636-12645.

Herder V., Wohlsein P., Peters M., Hansmann F. \& Baumgartner W. 2012. Salient lesions in domestic ruminants infected with the emerging so-called Schmallenberg virus in Germany. Vet. Pathol. 49:588-591.

Hoffmann B., Scheuch M., Hoper D., Jungblut R., Holsteg M., Schirrmeier H., Eschbaumer M., Goller K.V., Wernike K., Fischer M., Breithaupt A., Mettenleiter T.C. \& Beer M. 2012. Novel orthobunyavirus in cattle, Europe, 2011. Emerg. Infect. Dis. 18:469-472.

Holt D.E., Mover M.R. \& Brown D.C. 2010. Serologic prevalence of antibodies against canine influenza virus (H3N8) in dogs in a metropolitan animal shelter. J. Am. Vet. Med. Assoc. 237:71-73.

ICTV. International Commitee on Taxonomy of Viruses. On line. Accessed in June 6, 2013. <http://www.ictvonline.org/virusTaxonomy.asp>

Ishida S., Yoshizumi S., Ikeda T., Miyoshi M., Goto A., Matsubayashi K. \& Ikeda H. 2012. Detection and molecular characterization of hepatitis E virus in clinical, environmental and putative animal sources. Arch. Virol. 157:2363-2368

Jirjis F.F., Deshpande M.S., Tubbs A.L., Jayappa H., Lakshmanan N. \& Wasmoen T.L. 2010. Transmission of canine influenza virus (H3N8) among susceptible dogs. Vet. Microbiol. 144:303-309.

Kapoor A., Simmonds P., Gerold G., Qaisar N., Jain K., Henriquez J.A., Firth C., Hirschberg D.L., Rice C.M., Shields S. \& Lipkin W.I. 2011. Characterization of a canine homolog of hepatitis $\mathrm{C}$ virus. Proc. Natl Acad. Sci. USA 108:11608-11613.

Kirkland P.D., Finlaison D.S., Crispe E. \& Hurt A.C. 2010. Influenza virus transmission from horses to dogs, Australia. Emerg. Infect. Dis. 16:699702.

Larska M., Polak M.P., Riitho V., Strong R., Belak S., Alenius S., Uttenthal A. \& Liu L. 2012. Kinetics of single and dual infection of calves with an Asian atypical bovine pestivirus and a highly virulent strain of bovine viral diarrhoea virus 1. Comp. Immunol. Microbiol. Infect. Dis. 35:381390.

Lee K.E., Umapathi T., Tan C.B., Tjia H.T., Chua T.S., Oh H.M., Fock K.M., Kurup A., Das A., Tan A.K. \& Lee W.L. 1999. The neurological manifestations of Nipah virus encephalitis, a novel paramyxovirus. Ann. Neurol. 46:428-432.

Lefeuvre P., Lett J.M., Varsani A. \& Martin D.P. 2009. Widely conserved recombination patterns among single-stranded DNA viruses. J. Virol. 83:2697-2707.

Lima F.E.S., Santos H.F., Knak M.B., Scheffer C.M., Slongo J., Varela A.P.M., Cibulski S.P., Finoketti F., Roehe P.M. \& Franco A.C. 2012. Detection of avian gyrovirus type 2 in an Alagoas Curassow (Mitu mitu). Virus Rev. Res. 17:508

Lyons S., Kapoor A., Sharp C., Schneider B.S., Wolfe N.D., Culshaw G., Corcoran B., Mcgorum B.C. \& Simmonds P. 2012. Nonprimate hepaciviruses in domestic horses, United kingdom. Emerg. Infect. Dis. 18:1976-1982.

Maggi F., Macera L., Focosi D., Vatteroni M.L., Boggi U., Antonelli G., Eloit M. \& Pistello M. 2012. Human gyrovirus DNA in human blood, Italy. Emerg. Infect. Dis. 18:956-959.

Martin D.P., Biagini P., Lefeuvre P., Golden M., Roumagnac P. \& Varsani A. 2011. Recombination in eukaryotic single stranded DNA viruses. Viruses 3:1699-1738.

Mavrommatis B., Young G.R. \& Kassiotis G. 2013. Counterpoise between the microbiome, host immune activation and pathology. Curr. Opin. Immunol. (In publication)

Meng X.J. 2011. From barnyard to food table: the omnipresence of hepatitis E virus and risk for zoonotic infection and food safety. Virus. Res. 161:23-30.

Meng X.J., Halbur P.G., Haynes J.S., Tsareva T.S., Bruna J.D., Royer R.L., Purcell R.H. \& Emerson S.U. 1998. Experimental infection of pigs with the newly identified swine hepatitis E virus (swine HEV), but not with human strains of HEV. Arch. Virol. 143:1405-1415.

Mirazo S., Ramos N. \& Arbiza J. 2012. Molecular epidemiology of hepatitis E virus (HEV) in South America: current status. Virus Rev. Res. 17:5059.

Mochizuki M., Yachi A., Ohshima T., Ohuchi A. \& Ishida T. 2008. Etiologic study of upper respiratory infections of household dogs. J. Vet. Med. Sci. 70:563-569.

OIE. Schmallenberg virus. On line. Accessed in June 6, 2013. <http://www. oie.int/en/our-scientific-expertise/specific-information-and-recommendations/schmallenberg-virus/>

Okamoto H. 2007. Genetic variability and evolution of hepatitis E virus. Virus. Res. 127:216-228.

Okano H., Nakano T., Sugimoto K., Takahashi K., Nagashima S., Takahashi M., Arai M. \& Okamoto H. 2013. High genomic similarity between European type hepatitis $\mathrm{E}$ virus subgenotype $3 \mathrm{e}$ strains isolated from an acute hepatitis patient and a wild boar in Mie. Japan. Hepatol. Res. (In publication)

Oliveira-Filho E.F., Konig M. \& Thiel H.J. 2013. Genetic variability of HEV isolates: inconsistencies of current classification. Vet. Microbiol. 165:148-154.

Parrish C.R. \& Carmichael L.E. 1983. Antigenic structure and variation of canine parvovirus type-2, feline panleukopenia virus, and mink enteritis virus. Virology 129:401-414.

Payungporn S., Crawford P.C., Kouo T.S., Chen L.M., Pompey J., Castleman W.L., Dubovi E.J., Katz J.M. \& Donis R.O. 2008. Influenza A virus (H3N8) in dogs with respiratory disease, Florida. Emerg. Infect. Dis. 14:902-908.

Pecoraro H.L., Lee J.S., Achenbach J., Nelson Jr S. \& Landolt G.A. 2012. Seroprevalence of canine influenza virus (H3N8) in Iditarod racing sled dogs. Can. Vet. J. 53:1091-1094.

Phan T.G., Li L., O’ryan M.G., Cortes H., Mamani N., Bonkoungou I.J., Wang C., Leutenegger C.M. \& Delwart E. 2012. A third gyrovirus species in human faeces. J. Gen. Virol. 93:1356-1361.

Quan P.L., Firth C., Conte J.M., Williams S.H., Zambrana-Torrelio C.M., Anthony S.J., Ellison J.A., Gilbert A.T., Kuzmin I.V., Niezgoda M., Osinubi M.O., Recuenco S., Markotter W., Breiman R.F., Kalemba L., Malekani J., Lindblade K.A., Rostal M.K., Ojeda-Flores R., Suzan G., Davis L.B., Blau D.M., Ogunkoya A.B., Alvarez Castillo D.A., Moran D., Ngam S., Akaibe D., Agwanda B., Briese T., Epstein J.H., Daszak P., Rupprecht C.E., Holmes E.C. \& Lipkin W.I. 2013. Bats are a major natural reservoir for hepaciviruses and pegiviruses. Proc. Natl Acad. Sci. USA 110:8194-8199.

Ridpath J.F., Falkenberg S.M., Bauermann F.V., Vanderley B.L., Do Y., Flores E.F., Rodman D.M. \& Neill J.D. 2013. Comparison of acute infection of calves exposed to a high-virulence or low-virulence bovine viral diarrhea virus or a HoBi-like virus. Am. J. Vet. Res. 74:438-442.

Rijsewijk F.A., Dos Santos H.F., Teixeira T.F., Cibulski S.P., Varela A.P., Dezen D., Franco A.C. \& Roehe P.M. 2011. Discovery of a genome of a distant 
relative of chicken anemia virus reveals a new member of the genus Gyrovirus. Arch. Virol. 156:1097-1100.

Rivailler P., Perry I.A., Jang Y., Davis C.T., Chen L.M., Dubovi E.J. \& Donis R.O. 2010. Evolution of canine and equine influenza (H3N8) viruses co-circulating between 2005 and 2008. Virology 408:71-79.

Sauvage V., Cheval J., Foulongne V., Gouilh M.A., Pariente K., Manuguerra J.C., Richardson J., Dereure O., Lecuit M., Burguiere A., Caro V. \& Eloit M. 2011. Identification of the first human gyrovirus, a virus related to chicken anemia virus. J. Virol. 85:7948-7950.

Schat K.A. 2009. Chicken anemia virus. Curr. Top. Microbiol. Immunol. 331:151-183.

Schirrmeier H., Strebelow G., Depner K., Hoffmann B. \& Beer M. 2004. Genetic and antigenic characterization of an atypical pestivirus isolate, a putative member of a novel pestivirus species. J. Gen. Virol. 85:36473652.

Segales J., Kekarainen T. \& Cortey M. 2013. The natural history of porcine circovirus type 2: from an inoffensive virus to a devastating swine disease? Vet. Microbiol. 165:13-20.

Selvey L.A., Wells R.M., Mccormack J.G., Ansford A.J., Murray K., Rogers R.J., Lavercombe P.S., Selleck P. \& Sheridan J.W. 1995. Infection of humans and horses by a newly described morbillivirus. Med. J. Aust. 162:642645.

Simmonds P. 2013. The origin of hepatitis C virus. Curr. Top. Microbiol. Immunol. 369:1-15.

Simons J.N., Pilot-Matias T.J., Leary T.P., Dawson G.J., Desai S.M., Schlauder G.G., Muerhoff A.S., Erker J.C., Bujik S.L. \& Chalmers N.L. 1995. Identification of two flavivirus-like genomes in the GB hepatitis agent. Proc. Natl Acad. Sci. USA 92:3401-3405.

Stahl K. \& Alenius S. 2012. BVDV control and eradication in Europe - an update. Jpn. J. Vet. Res. 60 Suppl:S31-39.

Ståhl K., Kampa J., Alenius S., Persson Wadman A., Baule C., Aiumlamai S. \& Belák S. 2007. Natural infection of cattle with an atypical 'HoBi'-like pestivirus: implications for BVD control and for the safety of biological products. Vet. Res. 38:517-523.

Stalder H.P., Meier P., Pfaffen G., Wageck-Canal C., Rufenacht J., Schaller P., Bachofen C., Marti S., Vogt H.R. \& Peterhans E. 2005. Genetic heterogeneity of pestiviruses of ruminants in Switzerland. Prev. Vet. Med. 72:3741; discussion p.215-219.

Tarlinton R., Daly J., Dunham S. \& Kydd J. 2012. The challenge of Schmallenberg virus emergence in Europe. Vet. J. 194:10-18.

Truyen U. \& Parrish C.R. 2013. Feline panleukopenia virus: its interesting evolution and current problems in immunoprophylaxis against a serious pathogen. Vet. Microbiol. 165:29-32.

Varela M., Schnettler E., Caporale M., Murgia C., Barry G., Mcfarlane M., McGregor E., Piras I.M., Shaw A., Lamm C., Janowicz A., Beer M., Glass M., Herder V., Hahn K., Baumgartner W., Kohl A. \& Palmarini M. 2013. Schmallenberg virus pathogenesis, tropism and interaction with the innate immune system of the host. PLoS Pathog. 9:e1003133.

Vasickova P., Machackova E., Lukesova M., Damborsky J., Horky O., Pavlu H., Kuklova J., Kosinova V., Navratilova M. \& Foretova L. 2007. High occurrence of BRCA1 intragenic rearrangements in hereditary breast and ovarian cancer syndrome in the Czech Republic. BMC Med. Genet. 8:32.

Wensvoort G. 1993. Lelystad virus and the porcine epidemic abortion and respiratory syndrome. Vet. Res. 24:117-124.

Wernike K., Nikolin V.M., Hechinger S., Hoffmann B. \& Beer M. 2013. Inactivated Schmallenberg virus prototype vaccines. Vaccine 31:3558-3563.

Wilhelm B.J., Rajic A., Greig J., Waddell L., Trottier G., Houde A., Harris J., Borden L.N. \& Price C. 2011. A systematic review/meta-analysis of primary research investigating swine, pork or pork products as a source of zoonotic hepatitis E virus. Epidemiol. Infect. 139:1127-1144.

Yanase T., Kato T., Aizawa M., Shuto Y., Shirafuji H., Yamakawa M. \& Tsuda T. 2012. Genetic reassortment between Sathuperi and Shamonda viruses of the genus Orthobunyavirus in nature: implications for their genetic relationship to Schmallenberg virus. Arch. Virol. 157:1611-1616. 